\title{
A discussion on Mansfield's Tragic Theme of her later works
}

\author{
Wei Yang ${ }^{\mathrm{a}}$ and Xiuwen Li \\ Changchun University of Technology, Changchun 130012, China
}

\begin{abstract}
Katherine, Mansfield is among the very few writers in English to establish a reputation on the basis of short story form. That bringing her fame "Joyce of short stories" should give credit to her later works. Her fictions and her life were tightly interlocked. Just due to her extremely rough experience and vicissitude of life, we can see her revelation or fatalism as well as pessimistic. The First World War left its mark upon her outlook, so like other post-war intellectuals of the "Lost Generation", her philosophy grew to be one of pessimism and disillusionment in life. Thus she expressed a common western mood—fatalism and tragedy of life in her novels, so Mansfield's stylistic tragic novel is composed of disillusionment, loneliness. In the following, I try to promulgate her tragic theme by capturing the sense of disillusionment, loneliness in The Garden Party, The Fly.
\end{abstract}

She chose the short story as her own particular form and handled it with considerable skill. Like Joseph Conrad and James Joyce, she wrote at a time when a breakthrough in the representation of reality was not only desirable but also possible in the English short story [1]. She has so penetrating a mind and such a talent for expression that she would be interesting whatever form she were using and whatever subject she were writing about [2].

Katherine Mansfield (1888-1923), is famous for short stories, her stories resemble in some ways of Chekhov. Many of her stories turn ordinary events in life into moments of unforgettable experience, present seemingly trivial incidents from daily life with exactly artistic crafts that made her own, thus they show us a universal truth of human life. She freely reflected the severe reality by few limited settings, and then displayed the theme naturally. That bringing her fame "Joyce of short stories" should give credit to her later works.

In the later stage, she excavated life rather deeply than before, moreover, the subject matter and forms also become rich and varied. Undoubtedly, each trivial in the novel was on the basis of her own experience. She had never written things she had never undergone. Just due to her extremely rough experience and vicissitudes of life, we can see her revelation or fatalism, pessimistic. From anther point of view, it's a general emotion at that time in western society.

\section{Disillusionment}

Disillusionment is one of the literary themes that Mansfield liked. It shows glorious hope of life that is shattered in a flash, and then emerges on immediately sense of loss as well as disconsolate.

The Garden Party is a representative example. It portrays several sections of the little girl Laura's one day's activity. The plot is very simple. While Laura's worldview is utterly different just in this short day. At the beginning, her guileless eyes simply sees beautiful things, so in her opinion, it doesn't exist hideous at all. The first half of the novel emerges many scenery descriptions that are full of affection. They are the bright bunches that reflect the inner world of Laura's heart.

"The weather was ideal. They could not have a more perfect day for a garden party if they had ordered it, windless, warm, the sky without a cloud. As for the roses, you could not help feeling they understand that roses are the only flowers that impress people at garden parties, the only flowers that everybody is certain of knowing. Hundreds, yes, literally hundreds had come out in a single night" [3].

Laura's perceptions here are limited to monomania anthropomorphism: outer stimuli are interpreted in terms of her anticipated happiness as her apprehensive excitement for the party burgeons.

It seems that music flowers, even the sunlight are blessing for her beautiful youth. The world's life is really perfect for her. Laura is about to pursue a happy life, and to plunge into the realistic society with full enthusiasm. The news of her neighbor's death through a fall from his horse is suddenly made known. It takes the story a sudden turn and then develops rapidly, the garden that overflowing the happy atmosphere just now is covered with a piece of dark cloud immediately: The peaceful life is broken abruptly.

For Laura, death of the workman changes her faith totally. While the neighbors are dealing with funeral arrangement, her families are about to sing merrily and dance gracefully, beating drums and striking songs. In Laura's opinion, that's quite flightily and savage. And

a Corresponding author: guotianbao1999@126.com 
Laura with her great sympathy for the poor and the wretched feels quite naturally that their garden party should be called off. But, everybody else laughs at her silly and stupid idea. Of course the party in the afternoon turns out to be a great success without any change.

The contrast of these two scenes opens two worlds for the readers at the same time: a world in her eyes and a world in her heart. From this point, it produces a striking contrast between the noisy outside world and the quiet inner world. Laugh and music serve as a further foil to the loneliness of death. Laura couldn't be calm. With her mother's food of condolence, she went to the neighbor's. "She took the basket to the cottage on a smoky and dark street quite nearby, entering timidly into the dead workman's house. The picture touched her slightly. She saw first his sister-in-law and then his wife and eventually the dead young man lying stretched out in his bedroom. Then she was hurried back with her cries and vague cogitations on life" [4]. At this time, Laura's sense of security vanished. She faced the cruel reality that was brought by the class difference. The objective fact threw a big shadow in her pure heart meanwhile brought her deep disillusionment. She began to realize life was not so perfect as she thought it. When she was out, she said "Isn't life- "isn't life-" What is life after all? She couldn't continue to give a complete and clear answer, because she was too young to understand and she had little experience.

The death of her miserable neighbor brought her the disillusionment. She started to recognize the other aspect of life and discover the true essence of life. Each thing has two aspects: Happy or depressed, joyous or sad, rich or poor, beauty or hideous as well as living and death. That's Laura's sudden realization on truth of life. This is a breach of human life. She was fearful that there were even death and poverty.

It's important to note these are also Mansfield's ideas. In the rest of her lifetime, Mansfield experienced so many life orbits: hope-pursue-shatter. Unfortunate marriage, roughly living and obstinate illness carved her sincere heart severely. There are so many wound to heal. Disillusionments are just the print left in her works. They are the prints of her detesting world.

This article is spread over the sense of disillusionment, and this is agreeing with the sense that in western after world war I. It's also a focal point many writers were interested in.

These disillusionments reflect her pain and sadness to varying degrees. She managed to face the reality bravely and to reveal the woman's independence, but the cruel reality always broke her wish into pieces, and these works reflect her thinking properly.

\section{Sense of loneliness}

Which aspect should we refer to if we want to create a good work? -Loneliness. This is Henry James' answer to his friend's question. Another famous short story writer also from Britain- Virginia Woolf is good at describing the extremely loneliness in spirit that is caused by people's indifference. While what about Mansfield?

Mansfield left home for living only at the age of 20 .
Three years later, when she came back to Wellington, the ignorance and backward area couldn't meet the needs of her excited heart at all. The life outside was extremely lonely and there was lack of understanding as well as caring in London. It was widely divergent with cherished and fragrant life in her illusion. It's hard to imagine how to remain in hometown again because she has accustomed freedom and opening life in London. Although Mansfield took London as her forever-alien land, but it isn't her root, she had fully experienced the sense of loneliness as if a duckweed. Therefore, loneliness from her life became one of her themes in novel creating, and she had lots of vivid portrayals of the lonely characters. Almost everyone in her novels seems to staring one's reflection and admires oneself. We can say the sense of loneliness has been seep into the soul, such as the Kelveys in The Doll's Douse.

No lover of children can read it without sensing a pity that comes near to tears. We can never forget the two forlorn little girls sitting on a big red drainpipe by the side of the road.

The author had eyes on emerging characters inner world, however she seldom described the mood directly, then induced to readers to understand the mentality by monologue, expression and the response of the third person. Mentalities are interpreted by the actions. While the author made an objective description.

"The girls get together, laughing and joking-concentrating a exciting topic: the fantastic doll's house. But they two have a stand beside the girls lonely pacing back and forth." The scene repeated: "the girls of her class are nudging, giggling together. The little girls pressed up lose. And the only two who stayed outside the ring were the two who were always outside, the little Kelveys" [5]

Another description of our Else also shows us this style.

"She was a tiny wishbone of a child, with cropped hair and enormous solemn eyes-a little white ow1. Nobody had ever seen her smile: she scarcely ever spoke" [6].

In these scenes, the author tried to make the readers unconscious of her existing. She didn't have any comment, but let the character act himself, show herself. She left us much room to make a full image. While for a child, life should have been lovely and happy. How could the little girl bear the gloomy? They were surrounding by the sense of loneliness from their childhood. The pressure of the loneliness was constrained to the heart. They were studying with the other children of the same age, but rejected far away from the group of boys and girls, all of who were interested in the doll's house: "the girls of her class are nudging, giggling together. The little girls' presses up close. And the only two who stayed outside the ring were the two who were always outside, the little Kelveys." Then what could they do?

"Only the little Kelveys moved away forgotten; there was nothing more for them to hear."

"She went throng life holding on to Lil, with a piece of Lil's skirt screwed up in her hand. Where Lil went, our Else followed, in the playground, on the road going to and from school. There was Lil marching in front and our Else holding on behind. Only when she wanted anything or when she was out of breath, our Else gave Lil a tug, a 
twitch. Lil stopped and turned round. They Kelveys never failed to understand each other" [7].

Nobody could understand. They belonged to different worlds. Only the two understood each other without being told. In the light of the loneliness, tracking down the origin, that is the conflict of class. We see the sharp contrast between the rich and poor, fortunate and miserable. That is a gap between the two social strata in the western world of poor laboring people and the idle rich, with the author very definitely sympathy for the lower class but at the same time rather calmly acknowledging and accepting the unbridgeable gap. There is thus the striking contradiction between the shallow and insignificant social content of the story on the one hand and the apparent psychological depth of the central figure on the other. From these contrasts, we realize the loneliness more clearly.

Mansfield is a writer out of the ordinary. There isn't any grand theme in her works. But she has a unique vision to sharply point out the true essence of life though they are the ordinary phenomenon. She is exploring and seeking for psychological art of contemporaries to show on. Thus, there isn't any towering but some natural things. Mansfield has a keen imaginative power, artistic tincture and a heart that is rich in thinking. She often mixed her feeling into her stories, and expressed by a character that has rich experience. When we read her books, the feelings of artistic and of life interweaved closely. She leads us with her works to inspect the joys and sorrows of life. That is the glamour of her creating.

Mansfield was struggling and exploring herself in a society, which is incompatible with her personality. While she is bearing the illness, at the same time reasonable and sharply wondering about the life. She is creating with the strong will, then became world famous for her works of striking personality. In all, there arises a sense of being dreary and lonely or be shocked by the death that is full of depressed and hopelessness after we have read her words. While that is the characteristic of Mansfield's novels.

\section{References}

1. Frank O'Connor, In the lonely Voice World, 128, 130-131 (1963).

2. J.C. Squire, In Books Reviewed. Hodder and Strongton, 10 (1922).

3. J.N. Chen, Foreign Literature Studies, 9, (2000).

4. W.R. Hou, Shanghai Foreign Language Education Press, (1996).

5. T.W. Jing, The eastern publishing co.Ltd, 12, 177, 180, 182, 191, 193, 196, 201 (1998).

6. T.W. Jing, Jilin Education Press, 1, (1999).

7. Y.B. Zhao, Y.H. Liang, Foreign Literature Studies, 3, (1999).

8. Z.Y. Wang, Science and Technology Information, 3, (2012).

9. W.J. Liang, Journal of Jiamusi Education Institute, 4, (2014)

10. X.H. Gao, Language Planning, 12, (2015).

11. L.B. Wang, Y.J. Cheng, Some Recent Trends of Overseas Katherine Mansfield Studies in the Past Three Decades.

12. Journal of University of Science and Technology of Suzhou, 1, (2016). 